\title{
扁平上皮癌脳転移
}

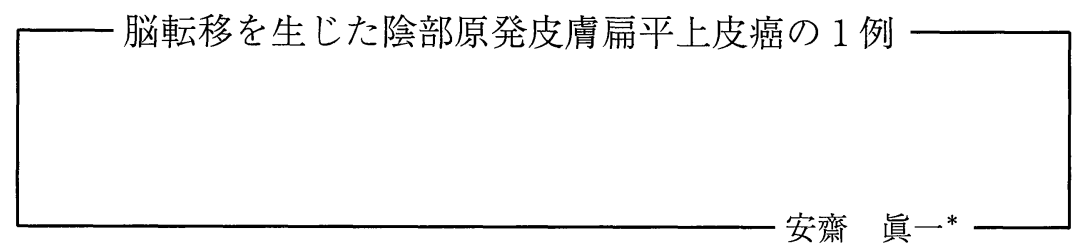

\section{A case of brain metastasis from genital squamous cell carcinoma of the skin}

Shin-ichi ANSAI

* Division of dermatology, Yamagata Prefectural Nihon-kai Hospital

I report a case of 50-year-old male with brain metastasis from genital squamous cell carcinoma of the skin. At his first visit, a giant tumor was seen on his lower abdomen and metastases to para-aortic lymph nodes were already observed as well as to inguinal and external iliac nodes. The tumor had slightly decreased in size by chemotherapy and irradiation. He complaint of loss of power in his both legs five months after his first visit. Multiple metastases to vertebrae, iliac bone and brain were detected by computed tomographic examination. He died of the tumor eight months after his first visit.

Brain metastasis from cutaneous squamous cell carcinoma is extremely rare, and to our best of knowledge, no other case has been reported other than direct invasion from squamous cell carcinoma arising on face. [Skin Cancer (Japan) $2001 ; 16$ : 44-46]

Key words : SCC, Brain metastasis, Genitalia, Born metastasis, Autopsy

はじめに

皮膚原発の扁平上皮癌は, 多くの場合その進 行は比較的穏やかであり，血行性遠隔転移は， その末期になるまでみられることは稀である。 今回我々は，初診時すでに所属リンパ節を越え た転移がみられ，最終的に多発性骨転移ととも に脳転移を生じた，陰部原発皮膚扁平上皮癌の 1 例を経験したので報告する。

* 山形県立日本海病院皮膚科
症例

症 例：50 歳, 男性。

初診:平成 9 年 7 月 14 日

家族歴・既往歴：特記すべき事項なし

現病歴：初診約 4 力月前に陰茎根部左側の腫 瘍に気付いた。急速に増大し，両側鼠径部の腫 脹も生じたため，当科初診した。

初診時現症：陰茎根部左側に握り拳大の表面 にびらん・壊死組織をつけた，下床との可動性 の極めて不良な外向発育性の腫瘍を認めた。ま た左鼠径部には鵎卵大・右鼠径部にはピンポン 
ボール大の堅くて可動性の悪いリンパ節腫脹を 認めた（図1)。

臨床検査成績: 一般臨床成績上は, LDH の上 昇と SCC 抗原の上昇がみられたのみである。調 べ得た限り肺・食道を含めた内臓には腫瘍像を 認めなかった。

CT 像：原発腫瘍とともに, 両側鼠径部に巨大 な腫瘍がみられ，さらに，骨盤内・傍大動脈り ンパ節の腫脹もみられた。胸部の検索では, さ らに縦隔内のリンパ節の腫脹も確認された。

生検組織像：腫瘍細胞は皮䖉全層から皮下組 織へと不規則に浸潤・増殖していた。強拡大で は，著明な核・細胞異型・異常核分裂像がみら れ，また，一部の腫瘍細胞巣では壊死像も観察 された。また, 個細胞角化も散見され, 標本上 他の附属器への分化はみられなかった（図2)。

全身検索の結果と併せて, 未分化な皮虐原発 扁平上皮癌 T4N1M1 STAGE4 と診断した。

治療と経過：治療は, ステージより考えて根 治手術は不可能と考え，まず， 7 月 28 日よりシ スプラチン・ドキソルビシン・ビンデシンによ る併用化学療法を施行した。2 クール終了時に 原発部の腫瘍の量が減少したが，十分ではな かったため 8 月 28 日より左鼠径部と原発腫瘍 に対し,ライナックによる放射線照射総量 61Gy を併用した。原発部の腫瘍は著明に減少し, 血 清中の SCC 抗原も減少した。しかし, 画像診断 上骨盤内・傍大動脈・縦隔のリンパ節の大きさ

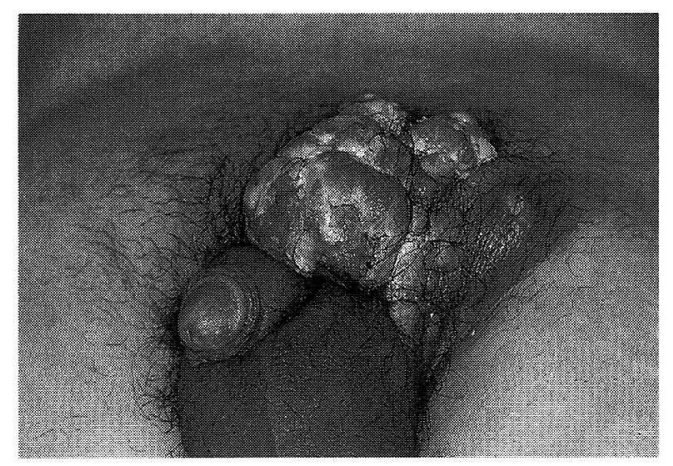

図 1. 初診時臨床像
は不変であり,さらに腸骨への腫瘍の浸潤·照 射野外での腫瘍の増大がみられたため，9月 29 日よりイリノテカンによる化学療法に切り替え た。イリノテカンは 1 回 $140 \mathrm{mg}$ 合計 4 回投与し た。イリノテカンによる重篤な副作用は観察さ れなかったものの, 局所の腫瘍の増大 - 画像上 骨盤内リンパ節の増大, 血清 SCC 值の増加を認 めたため, 12 月 2 日より右鼠径部と骨盤内リン パ節へのライナックによる放射線照射を計 $51 \mathrm{~Gy}$ 行った。照射野内の腫瘍にはある程度の効 果を認めたが, 左下肢の蜂巣織炎を繰り返し, さらに骨盤骨・脊椎への浸潤によると思われる 腰痛は進行性に増覀していた。12月 7 日頃よ り, 急速に両下肢の脱力が出現し, 起立・歩行 が不可能となった。

当初, 脊椎または脊髄への転移によるものと 考え検索したところ, 腰椎椎体と腸骨への転移 は確認されたが，整形外科的にこれによる脱力 とは考えにくいとのことであった。さらに頭部 CTを施行したところ, 図に示すように脳に多発 性の腫瘍像が観察された (図 3)。組織学的に確 認はしなかったが, 臨床像より㓌部腫瘍の脳へ の転移と診断し，副腎皮質ステロイド剂とフェ ニトインの投与を開始し, 腫瘍に対する積極的 な治療は行わず，モルヒネなどによる緩和ケア を主体に行うこととした。その後衰弱し, 経口 掑取が不能になったため, フェニトインの投与 を中止したところ, 痙攣発作を起こしたが，ジ

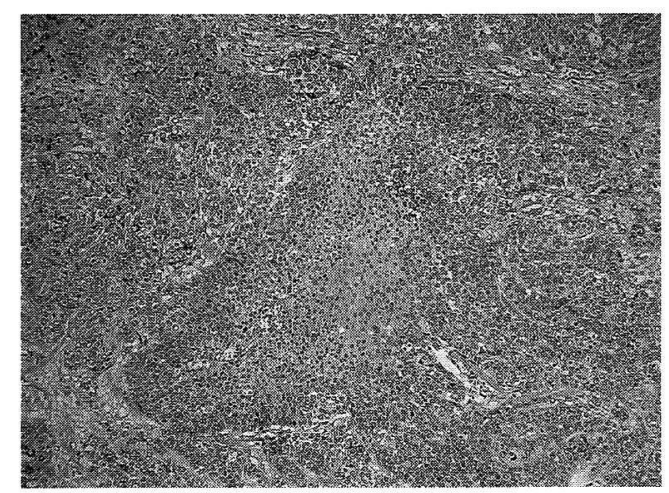

図 2.生検組織像 角化傾向に乏しい異型細胞の増殖が観察される 


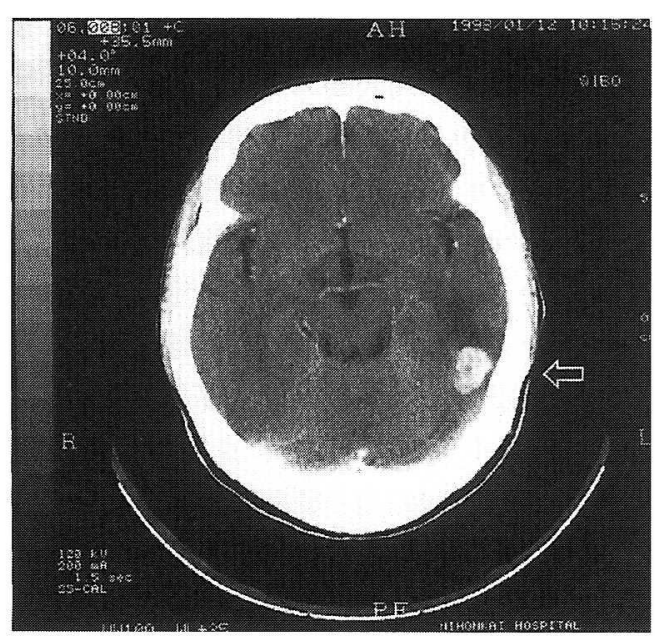

図 3. 脳 $\mathrm{CT}$ 像

脳内に造影剂で良く造影される腫瘍 $(\rightarrow)$ が 観察される

アゼパム・フェニトインの静注にて発作はコン トロールされた。患者は初診より約 8 力月後の 平成 10 年 3 月 2 日永眠された。

\section{考察}

皮膚原発扁平上皮癌は, 悪性黒色腫などと比 較すると多くの場合その経過は穏やかであり， 日本皮膚悪性腫瘍学会の調査でも, 初診時に所 属リンパ節転移を示す例は $10.7 \%$, 所属リンパ 節をこえる転移は $2.6 \%$ と稀である ${ }^{1 ! 。}$ 。本症例 は，初診時にすでに所属リンパ節を越える転移 が明らかであり，本人の申告通りとすれば，発 症より数カ月でそのような経過に至っているこ ととなり，かなり急速な進行をした腫瘍といえ よう。

組織学的に本症例はかなり未分化な形態を呈 しており，Broders 分類では grade 4 にあたるい わゆる spindle cell SCC としての形態を示して
いた。また，初診時かなりの進行を示していた ため, 内臓癌の皮膚転移も想定して検索を進め たが，その結果は否定的であった。

日本皮膚悪性腫瘍学会の調査した 1577 例中, 脳転移を確認した例は皆無であり ${ }^{1)}$ ，海外文献 においても，我々の調べえた範囲内で，顔面発 生のものが直接脳内へ浸潤した例の報告は散見 されたが2，脳への遠隔転移を生じた皮膚原発 扁平上皮癌の報告はみられなかった。本症例で もそうであったが,このような遠隔転移は，特 に皮覤原発扁平上皮癌に打いては末期にならな いと出現しないため, 脳転移による神経症状が 出ても，その診断をつけることによる予後の改 善が望めないので，検査されていない可能性は あると思われる。

本症例では，一時的に抗痓攣剂の投与が断絶 したときに㽷攣発作を起こして扮り，脳転移症 例に対する副婜皮質ホルモン剂・抗痙攣剤の投 与は, 病攣発作の予防に有効であったと考えら れる。皮膚原発扁平上皮癌症例においても，脳 転移は起こりうることを銘記し，予後の改善は 望めないとしても, 神経症状が生じたら, 積極 的に脳転移の有無を検索し, 㽷攣・䐉浮腫に対 する治療を行うことで，少しでも安楽に穏やか に長い生を得る手助けをすることが可能になる と考える。

\section{文献}

1）石原和之：有棘細胞癌一全国アンケートの結果と 説明. Skin Cancer, 9:72-77, 1994.

2) Simon, C.D., Sims, P.J., Elston, D.M. : Fatal cutaneous squamous cell carcinoma with extension through the maxillary sinus and orbit into the brain. Cuti, 63:341-3, 1999. 